\title{
1.4. MEASURING OF THE LABOUR MARKET SUCCESS OF GRADUATES OF THE SZENT ISTVÁN UNIVERSITY
}

\begin{abstract}
Summary
Graduate Career Tracking System (GCTS) surveys are well-known and widely accepted tools to follow up careers of the graduates and to evaluate their opinion on their jobs and tasks. This survey also may explore how the graduates think about the usefulness of their skills and competencies they gained during their university studies, how these competences are accepted by the labour market.

This case study is based on surveys carried on by the Graduate Career Tracking System at the Szent István University (SZIU) in Hungary. In the survey not only the classical economic indicators - such as wages, chance of becoming employed and the average time until starting the first job after graduation - were examined, but also some other factors like the link between the current and past job and the qualifications awarded, job satisfaction in various aspects of work, the technical part of the work, wages and benefits were also considered. The target population was analysed not only by the field of study (agricultural sciences, economics, engineering, teachers training, and liberal arts) but also by training level (BA/BSc, MA/MSc) as well.

According to the survey results, it is concluded that the graduates of Szent István University are more satisfied with the personal circumstances and the content of job, less satisfied by their opportunities of professional and career development, and they are least satisfied with their wages.
\end{abstract}

Keywords: labour market success, Graduate Career Tracking System, higher education, Principal Component Analysis, logistic regression model

\section{Introduction}

The Hungarian higher education has undergone several changes since the beginning of the 2000s. The three most important challenges are the decreasing number of students, the changes of the educational system (known as Bologna Process), and the uncertainty about the future role of the state in educational finance (Sipos and Kuráth, 2013). The Bologna process was implemented in European Higher education system in the academic year of 2006-2007. The main aim of the Bologna Process was to develop the European Higher Education Area, with a transparent and comparable educational system. The training became two-tiered (Bachelor and Master courses) in most of the study programs, with a flexible credit system, which allows a wider cooperation of the European countries in the field of higher education. (Sipos and Kuráth, 2013). One of the main aims of implementation of Bologna Process in European higher education system was to promote student mobility, the multicultural character of education and 
to support the modernization of education and training systems to make sure these meet the needs of a changing labour market. This is especially important in our times, as the young generation was also affected by the economic crisis and during the recovery the proportion of jobs requiring high skills grows, and the demand is shifting as structure of economies is changing (EC, 2015). Because of this and the increasing competition between universities every university need to get a clear picture about the success of their graduates on the labour market.

Higher educational institutions recognized the importance of gathering information about (and from) their graduates in order to assess and improve institutional quality, monitor employment outcomes, develop new programs and curricula. In many countries, graduate tracking systems were established at national or sub-national levels to provide information on graduates and their career paths. In a recent study, graduate tracking systems in ten countries have been analysed in terms of their authors, purposes, scopes and methods (Usher \& Marcucci, 2011)

There is an increasing number of researches working on finding suitable indicators and measurement technical things to give the required information and graduate tracking systems were also used for assessing institutional performance and institutional benchmarking. (Garton and Robinson, 2006; Joensen, 2009; Storen and Aamodt, 2010; Boden and Nedeva, 2010; Chowdry 2013; Varga, 2013; Veroszta, 2013; Mijic and Jankovic, 2014; Krawczyk, 2015).

This paper shows an alternative methodology and its application based on the experiences of Szent István University, Hungary.

Szent István University, is one of Hungary's largest institutions of higher education, was founded in 2000 by the merger of the University of Veterinary Science in Budapest, Ybl Miklós Technical College, the Teachers' Training College of Jászberény and the University of Agriculture in Gödöllö. After the recent structural and institutional changes, the SZIU has eight faculties with more than 14000 students. The university headquarters are located in Gödöllö, At the Gödöllö Campus, there are three faculties, the Faculty of Agricultural and Environmental Sciences, Faculty of Economics and Social Sciences and the Faculty of Mechanical Engineering. In Budapest, there are three faculties: Ybl Miklós Faculty of Architecture and Civil Engineering, Faculty of Food Sciences, Faculty of Horticulture and Faculty of Landscape Architecture. Faculty of Economics, Agriculture and Health Studies has three campuses all of them located in the Southern Great Plain region (Békéscsaba, Szarvas and Gyula). The education programmes cover all the three levels of the Bologna system: the university provides a wide range of Bachelor and Master courses, and has eight doctoral schools. Most of the courses have a full time and a part time educational system as well, and many programmes (Bachelor, Master and $\mathrm{PhD}$ level) are educated in English for foreign students.

The labour market success of graduates is most often measured by the higher level of wages after being more educated. The multi-dimensional aspects of labour market success have also been underlined by former researches (EC, 2015; Veroszta, 2010). Of course, labour success of young employees should not be measured only by salaries and better jobs, there are multi-layered indicators available. According to the 
suggestions of the European Centre for the Development of Vocational Training (CEDEFOP) the following indicators are used:

1. Transition from education to work;

2. Employability: on average, how likely it is that they will find a good and meaningful job after graduation;

3. Unemployment rate and probability of becoming unemployed;

4. Relationship between wages and educational attainment;

5. Qualification differences: discrepancies between graduates' level of education or skills and the level of education or skills required by their job (CEDEFOP, 2010).

\section{Material and methods}

In 2010, the Szent István University (SZIU) joined the national central system named the Graduate Career Tracking System (GCTS). Since 2010, an on-line survey (amongst students and graduated) has been carried out by the university.

This case study is based on surveys carried on, by the Graduate Career Tracking System (GCTS) in 2013, 2014, 2015 and 2016. The population of the sample was represented by those students who graduated in the previous year and have an active status at the labour market at the time of the survey. Students who continue their studies and are registered in a regular programme, are on maternity leave, or are having inactive status - i.e. inactive, dependant etc. were excluded from the research. In 2013, 333 graduates, in 2014, 343 graduates, in 2015, 478 and in 2016, 395 graduates were active in the labour market and were selected into the sample. Thus, the total number of the graduates' sample was 1549 persons. For the evaluation of the expected and real wages the students with active student status were also included into the research, the number of the sample of SZIU active students at the time of the survey in 2016 was 1371.

In the case of numeric variables, the lowest $2.5 \%$ and the highest $2.5 \%$ values were discarded form future analyses. During the analysis, the differences in the structure and overall level of labour market success were examined in the sub-populations formed by group creating factors. In the course of the research, the following statistical methods were applied: chi-square test, independent samples t-tests, one-way ANOVA, Principal Component Analysis, logistic regression models, generalized linear models. Statistical processing of data performed by the IBM SPSS 22 software package.

\section{Results and discussion}

Based on the results it can be stated that the labour market success of new graduates in could be indicated not only by wages but also by other factors, such as time for finding the first job and the link between their qualification and their profession. These results are in accordance with former researches of Varga (2013) and Vinogradov et al. (2015).

In spring of 2016, 83.5\% of those students who graduated in 2015 had a job. According to defining labour market status, $5.6 \%$ of them were unemployed. Other 
students have not had a job yet, because of starting further university studies $(8.6 \%)$, having children $(1.6 \%)$ or some other reasons $(0.7 \%)$.

At first, the objective factors of labour market success were examined, such as average wages, time until getting the first job and the percentage of graduates who are employed in their chosen academic fields. Based on the results of the independent samples t-test $(p<0.01)$ significant difference was shown between the two levels of education $(\mathrm{BA} / \mathrm{BSc}, \mathrm{MA} / \mathrm{MSc})$ only at the field of economics from the four examined fields of study (agriculture, economics, technology and others). It is worth to conduct additional studies as those students who graduated in the field of economics in the SZIU can expect better wages with (MA/MSc) Master's degree, compared to the BA/BSc degree (Figure 1).

Based on the result of the one-way ANOVA (LSD post hoc test: $p<0.01$ ) it is verified by statistical analyses that in case of technology field of study the graduates earn significantly more money than those students who graduated at agricultural and other programmes. At the Master (MA and MSc) courses the average wages of students graduated as economists exceed the wages of students graduated at agricultural and other fields of study. The average wages of students of the study field of technology is significantly higher (ANOVA, LSD post hoc test: $p<0,046)$ when compared to the agricultural field.

Figure 1: Average wages, job finding times and percentage of graduates who are employed in their chosen academic fields in the case of graduates of the SZIU in 2015

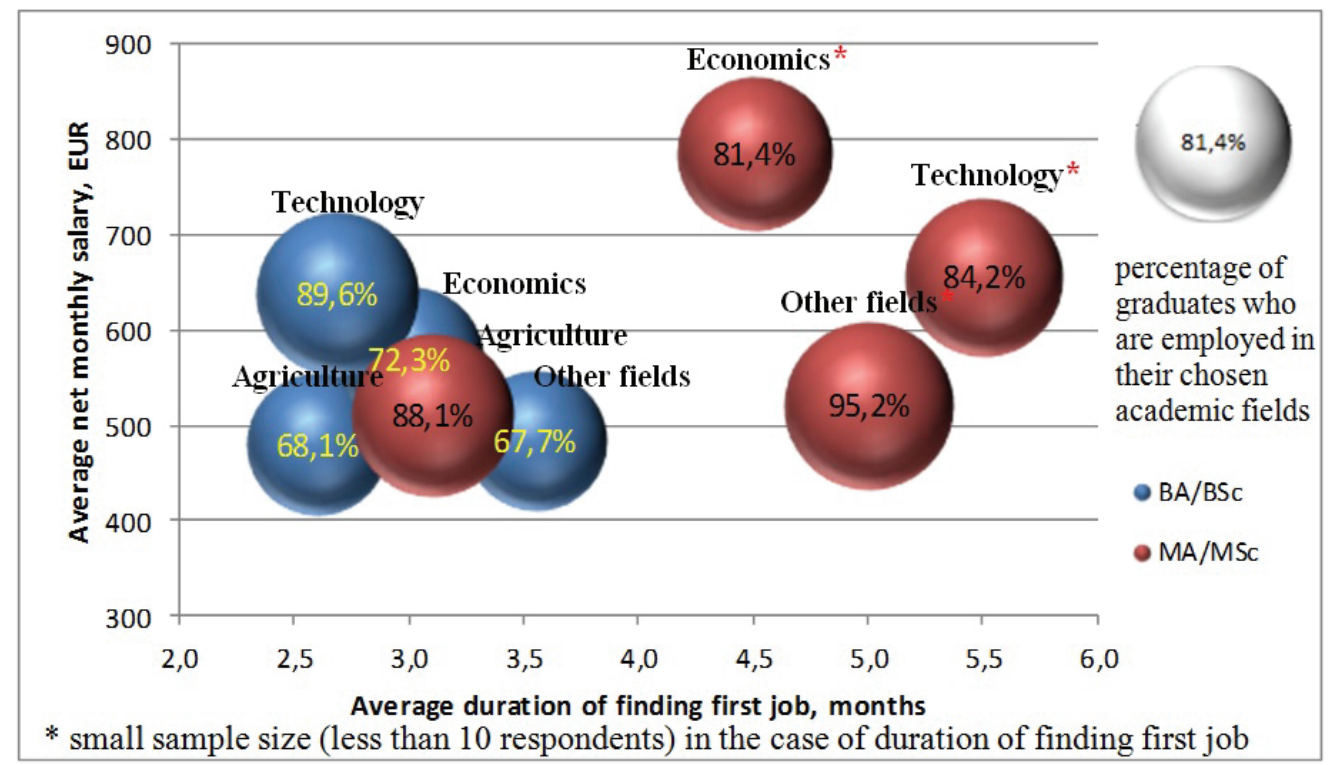

Source: primary research by the authors based on survey by "GCTS" SZIU in 2016

Based on the results of the one-way ANOVA ( $p>0.05)$, it can be stated that- in case of the BA/BSc degrees - there is no statistically significant difference between the fields of study in the average duration of finding first job after graduation.

In case of Master programmes (MA/MSc) the statistical analyses for the variable called 'Duration of finding the first job' could not be performed because of the small 
number of the sample. It shall be noted, that this question is relevant only for those students who started to find a job after graduation. $39.5 \%$ of the SZIU students who graduated in 2015 have already had job at the time of graduation, while $14.9 \%$ have not searched a job as they continue their studies or because of other reasons. Only $45.6 \%$ of freshly graduated SZIU students searched for job after graduation and $43.1 \%$ could find the first job in one month. Therefore, the question was related for only $25.9 \%$ of all graduated students.

These results should be worth to compare with recent researches on the entrepreneurial attitudes of university students (Veciana et al., 2005; Thorp and Goldstein, 2010; Gibcus et al., 2012; Farkas and S. Gubik, 2013; Illés et al., 2015; Szerb and Trumbull, 2015, Dunay et al., 2015.), as their results indicated that many of the students would prefer to work as entrepreneur.

The results of the chi-square test $(p=0.013)$ showed a significant difference between the fields of study in the percentage of graduates who are employed in their chosen academic fields. A higher proportion of students with Bachelor degree at technology field found a job at technology industry. In case of Master students, there were not significant differences between the fields of study and the jobs connected to the given profession fields. In the case of agriculture $(p=0.040)$ and other $(p=0.012)$ fields of studies a significant difference was detected between two the two levels of education (BA/BSc, MA/MSc), namely that graduates having Master's degree found a job at their own profession field in a significantly higher percentage (illustrated by the size of the circles in Figure 1).

In the next stage of the research the expected and required wages drafted by the respondents of the GCTS survey (i.e. active students) were compared to real wages declared by the students who graduated in the previous (2015) year (Figure 2).

Figure 2: Salary requirements and expected wages of the active students of the SZIU according to the average wages declared by graduates in 2015, by field and degree of study

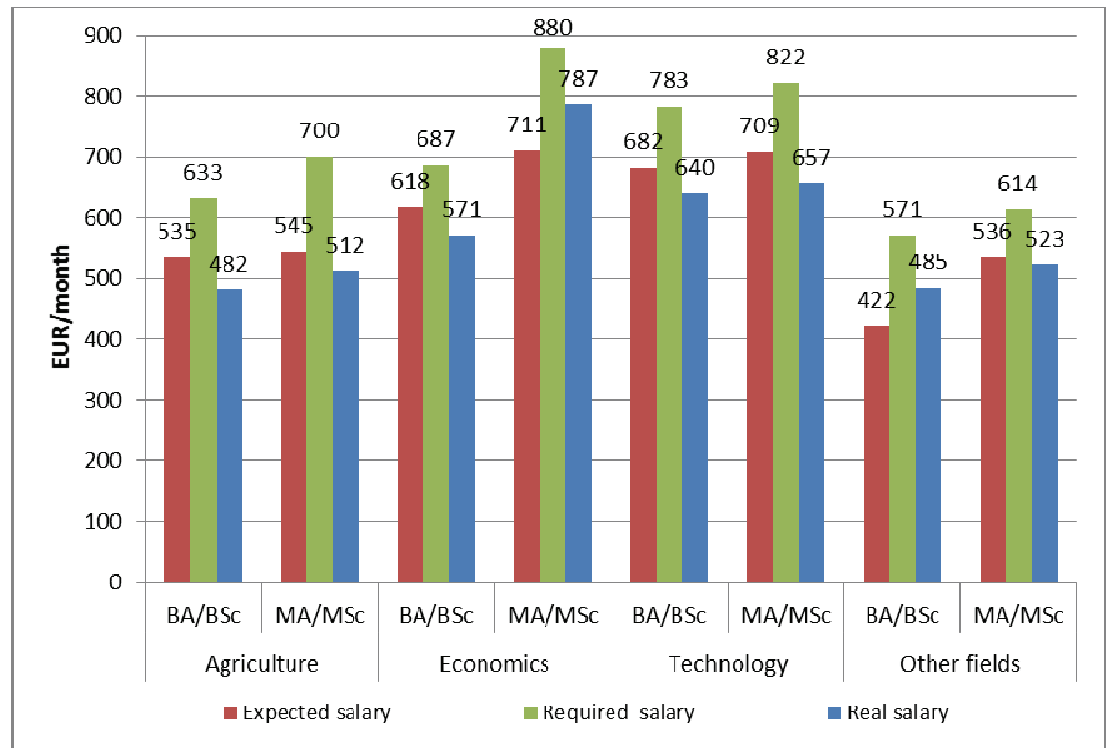

Source: primary research by the authors based on survey by "GCTS" SZIU in 2016 
Based on the results of the Mann-Whitney test (Table 1) only in case of the BA/BSc degree in other fields of study significant differences can be found between real and expected wages, namely, real wages are lower than the expected wages. Required wages significantly exceeds real wages, except in MA degree in economic field, where significant differences cannot be detected because of the high dispersion of values.

Table 1: Mean difference between real and expected or real and required wages in case of students with active status and graduates of the SZIU

\begin{tabular}{|c|c|c|c|c|c|c|c|c|}
\hline \multirow{4}{*}{$\begin{array}{l}\text { Differences between real, } \\
\text { expected and required wages }\end{array}$} & \multicolumn{8}{|c|}{ Fields of study } \\
\hline & \multicolumn{2}{|c|}{ Agriculture } & \multicolumn{2}{|c|}{ Economics } & \multicolumn{2}{|c|}{ Technology } & \multicolumn{2}{|c|}{ Other fields } \\
\hline & \multicolumn{8}{|c|}{ Degree of study } \\
\hline & $\begin{array}{l}\mathrm{BA} / \\
\mathrm{BSc}\end{array}$ & $\begin{array}{l}\mathrm{MA} / \\
\mathrm{MSc}\end{array}$ & $\begin{array}{l}\mathrm{BA} / \\
\mathrm{BSc}\end{array}$ & $\begin{array}{l}\mathrm{MA} / \\
\mathrm{MSc}\end{array}$ & $\begin{array}{l}\mathrm{BA} / \\
\mathrm{BSc}\end{array}$ & $\begin{array}{l}\mathrm{MA} / \\
\mathrm{MSc}\end{array}$ & $\begin{array}{l}\mathrm{BA} / \\
\mathrm{BSc}\end{array}$ & $\begin{array}{l}\mathrm{MA} / \\
\mathrm{MSc}\end{array}$ \\
\hline $\begin{array}{l}\text { Mean difference between real } \\
\text { and expected wage }\end{array}$ & -16.7 & -10.1 & -14.5 & 23.6 & -13.3 & -16.1 & $19.7^{*}$ & -4.0 \\
\hline $\begin{array}{l}\text { Mean difference between real } \\
\text { and required wage }\end{array}$ & $-47.0^{* *}$ & $-58.5^{* *}$ & $-36.0^{* *}$ & -29.2 & $-44.6^{* *}$ & $-51.4^{*}$ & $-26.6^{*}$ & $-28.3^{*}$ \\
\hline
\end{tabular}

the difference is significant at 0.05 level, ${ }^{* *}$ the difference is significant at 0.01 level

Source: primary research by the authors based on survey by "GCTS" SZIU in 2016

The success of graduates in the labour market has been measured by indicator system, which we summarized in Table 2 .

It should be noted, that the elaborated indicator system is eligible for using the labour market success of the higher educational programmes, and not for the individual success of the graduated students.

In order to be classified into 'Success' category, all 'Indicators of success' should be fulfilled, whereas the criteria of classifying into the 'Non-success' category was the presence of at least one 'Indicator of non-success'. There were 1549 graduates in our sample, among them 64 respondents $(4.1 \%)$ met fully the criteria system of labour market success, 841 respondents $(54.3 \%)$ were classified into the 'Non-success' category.

It should be underlined that the classification into the 'Non-success' category do not mean the failure of the fresh graduates at the labour market. For instance, in aa special case, the graduated student would be grouped into the 'Non-success' category however he/she is among the most successful graduates based on the objective criteria (wages, job finding period) and he/she would be satisfied by the working conditions, but the job would not be connected his/her education and knowledge level. 
Table 2: Indicator system measuring the labour market success or failure of higher education programs in the case of SZIU

\begin{tabular}{|c|c|c|}
\hline Dimension & Indicator of success & Indicator of non-success \\
\hline $\begin{array}{l}\text { The way from the } \\
\text { education to world } \\
\text { of work }\end{array}$ & $\begin{array}{l}\text { Getting a full-time job during the } \\
\text { GCTS study or finding a job } \\
\text { within four months after the } \\
\text { graduation }\end{array}$ & $\begin{array}{l}\text { Lack of job for the period after the } \\
\text { graduation till the time of the } \\
\text { GCTS survey or finding a job later } \\
\text { than six months after graduation }\end{array}$ \\
\hline Wages & Top $25 \%$ of the rank of the wages & $\begin{array}{l}\text { Bottom } 25 \% \text { of the rank of the } \\
\text { wages }\end{array}$ \\
\hline $\begin{array}{l}\text { The current labour } \\
\text { market situation }\end{array}$ & $\begin{array}{l}\text { Employment status is permanent } \\
\text { and indefinite }\end{array}$ & -- \\
\hline $\begin{array}{l}\text { Connection (link) } \\
\text { between } \\
\text { professions and } \\
\text { jobs }\end{array}$ & $\begin{array}{l}\text { The job is connected to the } \\
\text { diploma or the specialization and } \\
\text { the knowledge and skills achieved } \\
\text { during the studies are used at least } \\
\text { to a medium extent in the current } \\
\text { work }\end{array}$ & $\begin{array}{l}\text { The knowledge and skills } \\
\text { achieved during the studies are not } \\
\text { used, or used at a minimum extent } \\
\text { in the current work }\end{array}$ \\
\hline $\begin{array}{l}\text { Employee (job) } \\
\text { satisfaction }\end{array}$ & $\begin{array}{l}\text { Top } 25 \% \text { of the rank of six aspects } \\
\text { giving ratings scale scores by } 4 \text { - } \\
\text { grade Likert-scale }\end{array}$ & $\begin{array}{l}\text { Bottom } 25 \% \text { of the rank of six } \\
\text { aspects giving ratings scale scores } \\
\text { by 4-grade Likert-scale }\end{array}$ \\
\hline
\end{tabular}

Source: primary research by the authors based on the indicator system compiled by Vinogradov et al. (2015)

Factors affecting the labour market success/not-success of higher education programs examined by Binary Logistic Regression model (Table 3).

Table 3: Factors affecting the labour market success (Binary Logistic Regression model)

\begin{tabular}{|l|l|l|}
\hline Factor & p-value & $\operatorname{Exp}(\mathrm{B})$ \\
\hline Educational field: economics (ref.: agricultural) & 0.246 & 1.652 \\
\hline Educational field: technical (ref.: agricultural) & $\mathbf{0 . 0 1 2}$ & $\mathbf{3 . 0 8 5}$ \\
\hline Educational field: other (ref.: agricultural) & 0.087 & 0.298 \\
\hline Educational form: MA/MSc (ref:: BA/BSc) & 0.167 & 1.553 \\
\hline Result: pass (ref.: very good) & 0.582 & 1.970 \\
\hline Result: satisfactory (ref.: very good) & 0.635 & 0.834 \\
\hline $\begin{array}{l}\text { Did he/she also obtain his/her degree directly after the pre-degree } \\
\text { certificate?: Yes (ref: No) }\end{array}$ & $\mathbf{0 . 0 4 3}$ & $\mathbf{2 . 0 3 7}$ \\
\hline Has he/she learned abroad during the study: Yes (ref: No) & 0.072 & 2.129 \\
\hline $\begin{array}{l}\text { Labour market status during the study: full-time employees (ref.: full- } \\
\text { time students) }\end{array}$ & 0.094 & 2.331 \\
\hline
\end{tabular}

Nagelkerke R Square $=0,648, \mathrm{n}=874$

Source: primary research by the authors based on survey by "GCTS" SZIU in 2013, 2014, 2015 and 2016

A further analysis was focused on job satisfaction of entrant workers. According to the data of the survey examined three years, the entrants were the most satisfied with the conditions of personnel, materials and substantive parts of the work and were the least content with income and benefits (Figure 3). 
Vinogradov, S.

Figure 3: Job satisfaction of certain aspects by giving scale scores in average

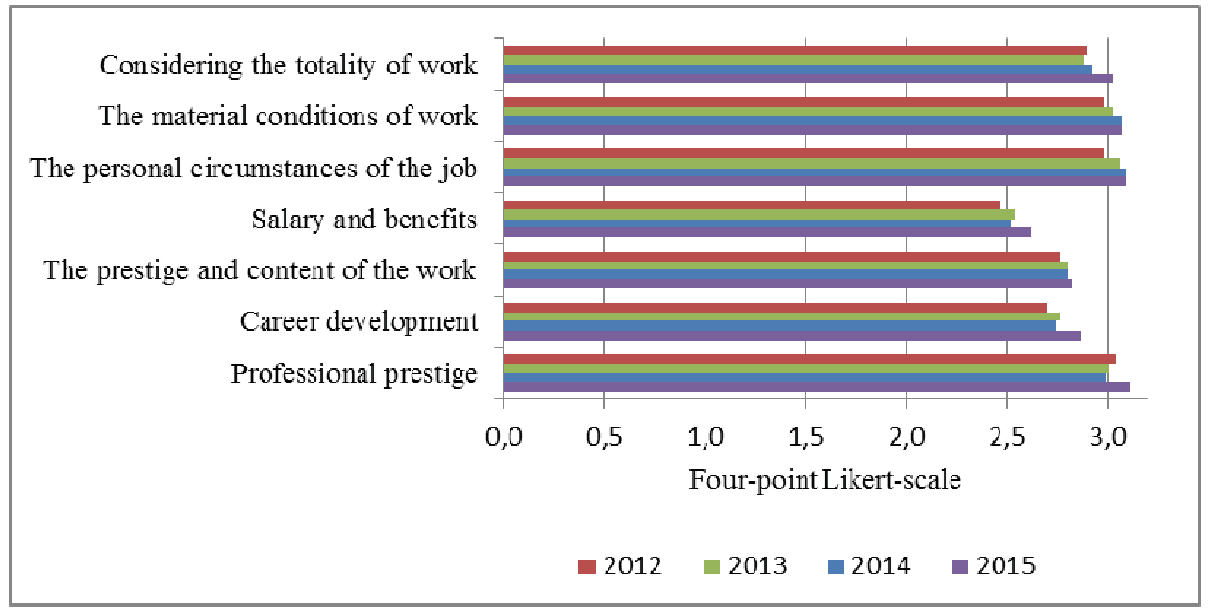

Source: primary research by the author based on survey by "GCTS" SZIU in 2013, 2014, 2015 and 2016

They were less satisfied with career opportunities at the beginning of their professional career linked to career challenges. The average was not on the negative side of the four-point scale in any dimension at all. Based on answers of certain aspects of job satisfaction, an overall rating indicator has been created by the principal component analysis. The authors say that that the principal component as standardized numerical character is the most suitable to make a summary characterization about the job satisfaction.

The last steps of the analysis were to establish the linear regression model in order to identify factors that influence job satisfaction. Aggregate principal components measuring job satisfaction (Table 4.) are the target variables of models, the explanatory variables of model, the dichotomizing range of quality properties and natural logarithm of the net wage from the main job per month.

Table 4: Job satisfaction aggregated measured by principal components examined in 2012, 2013, 2014 and 2015

\begin{tabular}{|l|c|c|c|c|}
\hline \multirow{2}{*}{\multicolumn{1}{|c|}{ Point of view }} & \multicolumn{4}{c|}{ Year } \\
\cline { 2 - 5 } & 2012 & 2013 & 2014 & 2015 \\
\hline Career development & 0.781 & 0.788 & 0.834 & 0.815 \\
\hline Professional prestige & 0.817 & 0.847 & 0.816 & 0.802 \\
\hline The prestige and content of the work & 0.775 & 0.825 & 0.812 & 0.808 \\
\hline The material conditions of work & 0.714 & 0.785 & 0.786 & 0.783 \\
\hline The personal circumstances of the job & 0.774 & 0.787 & 0.782 & 0.794 \\
\hline Income, benefits & 0.675 & 0.728 & 0.708 & 0.716 \\
\hline KMO & 0.829 & 0.856 & 0.844 & 0.876 \\
\hline Bartlett's test & $\mathrm{p}<0.01$ & $\mathrm{p}<0.01$ & $\mathrm{p}<0.01$ & $\mathrm{p}<0.01$ \\
\hline \% of Variance & 57.36 & 63.05 & 62.53 & 61.94 \\
\hline
\end{tabular}

Source: primary research by the authors based on survey by "GCTS" SZIU in 2013, 2014, 2015 and 2016 
Based on a determination multiple coefficients of linear regression models (Table 5.) we can conclude that the established models can only explain a small part of the job satisfaction among new graduated students of Szent István University.

Table 5: Variables of job satisfaction standardized beta values in generalized linear models

\begin{tabular}{|c|c|c|c|c|}
\hline \multirow{2}{*}{ Explanatory variables +} & \multicolumn{4}{|c|}{ Year } \\
\hline & 2012 & 2013 & 2014 & 2015 \\
\hline Net wage per month $(\ln )$ & 0.088 & 0.196 & $0.310^{*}$ & 0.381 \\
\hline Educational field: Economics (ref.: agricultural) & 0.168 & $\mathbf{0 . 5 6 0 *}$ & -0.375 & 0.066 \\
\hline Educational field: Technical (ref.: agricultural) & 0.118 & 0.256 & $-0.483^{*}$ & -0.527 \\
\hline Results, average: Excellent (ref.:good) & $0.527^{*}$ & -0.105 & 0.270 & 0.360 \\
\hline Did you learned abroad during the study: Yes (ref.: No) & -0.054 & 0.379 & $0.722 * * *$ & 0.095 \\
\hline $\begin{array}{l}\text { What extent do you use that knowledge in your work, } \\
\text { which you learned during your studies: Not at all (ref.: } \\
\text { Totally) }\end{array}$ & $-0.954^{*}$ & -0.252 & -0.536 & -0.723 \\
\hline $\begin{array}{l}\text { What extent do you use that knowledge in your work, } \\
\text { which you learned during your studies: A little bit (ref.: } \\
\text { Totally) }\end{array}$ & $-0.582^{*}$ & -0.095 & -0.338 & -0.653 \\
\hline $\mathrm{R}^{2}, \%$ & 20.7 & 9.2 & 11.7 & 16.2 \\
\hline
\end{tabular}

+ The table contains only information of the significant impact variables.

${ }^{*}$ the difference is significant at the 0.05 level, ${ }^{* *}$ the difference is significant at the 0.01 level

Source: primary research by the authors based on survey by "GCTS" SZIU in 2013, 2014, 2015 and 2016

In four years examined the effect of different factors were proved to be significant of job satisfaction. Those students who achieved outstanding academic results in 2012, they were more satisfied with their jobs. The fact that the graduates were unable to use their professional skills in their job, it is significantly reduced their job satisfaction.

Those students who graduated in economic fields in 2013, they were more satisfied with their jobs compared to graduates in agricultural fields. The positive effect of monthly net wages on job satisfaction is significant only amongst graduates in 2014 and in 2015. Among the same students graduated in technical fields were less satisfied with their jobs compared to graduates in agricultural fields. This fact should be considered in the formulation of new training curricula (Daróczi and Illés, 2014). The participation of foreign studies has a significant positive effect, which can only appear amongst students graduated in 2014.

Based on the results of empirical research the effected factors were not significant:

- Educational levels (BA/BSc, MA/MSc),

- Forms of study (full-time, correspondence),

- Working status during the studies (studying while working, "full-time" studying),

- Measured variables of support from the family:

- Education level of mother (graduated, not graduated), Relative financial situation of the family (Much worse than the average - Average - Slightly better than the average -Much better than the average). 
Among the explanatory variables there were indicators measured not only the over- but the under qualification as well.

Over-qualification means when new graduates get jobs with less expectations compared to the education of their own. The results of the survey amongst graduated in Szent István University a year ago, has not been confirmed that over- and underqualification could have less influence on job satisfaction.

\section{Conclusions}

The survey results of graduates in Szent István University have been confirmed by the results of national representative surveys based on the Graduate Course Tracking System in 2011 (Kiss, 2013). It is typical of graduates of Szent István University too that they are more satisfied with the personal circumstances and the content of job, they are less appreciated for their opportunities of professional and career development, and they are the least satisfied with their incomes. The common denominator is the main component, which can explain more than half of six variables variance measuring job satisfaction. The monthly net wages are relatively not so significant compared to other aspects of job satisfaction. Considering the job satisfaction factors used by linear regression models, we can say that the results are not in line in every aspect with the results of two surveys. Unlike the results of a national study, we have not statistically demonstrated that over-qualification could cause decreasing effect on job satisfaction amongst graduated in Szent István University. The determinants of labour market success of graduates have been evaluated by the binary logistic regression. Based on the results of empirical researches, we can say that students who graduated in technical fields have 18 times greater chance for success in labour market, compared to graduates in agricultural fields. Having Master's (MA/MSc) degree provides 3.2 times greater chance for success in labour market compared to having $\mathrm{BA} / \mathrm{BSc}$ degree.

Those students who continue their studying while working, they have 17.6 times greater chance for success in labour market compared to "full time" learning.

\section{References}

1. Boden, R.; Nedeva, M. (2010): Employing discourse: universities and graduate 'employability'. Journal of Education Policy Vol. 25. No. 1. http://dx.doi.org/10.1080/02680930903349489

2. CEDEFOP - European Centre for the Development of Vocational Training (2010). The skill matching challenge. Analysing skill mismatch and policy implications, $93 \mathrm{p}$. Publications Office of the European Union, Luxembourg.

3. Chowdry, H., Crawford, C., Dearden, L., Goodman, A., Vignoles, A. (2013): Widening participation in Higher Education: analysis using linked administrative data. Journal of the Royal Statistical Society: Series A (Statistics in Society), Volume 176, Issue 2, 431-457.

4. Daróczi, M., Illés, B. Cs. (2014): Challenges of Technical Education and Training in Agriculture. pp. 308-319. In: Illés, Dunay, Slocinska (eds.) New Trends in Management in the 21 st Century. 413 p. Czestochowa University of Technology 
5. Dunay, A., Swadzba, U., Vinogradov, S., Illés, B. Cs. (2015): Magyar egyetemi hallgatók pénzügyi tudatossága és vállalkozói attitüdje (Economic awareness and entrepreneurial attitudes of Hungarian university students.), pp. 516-528. In: Veresné Somosi M., Lipták K. (szerk.) „Balance and Challenges” IX. International Scientific Conference Proceedings. Miskolc, Hungary, 948 p.

6. European Commission/EACEA/Eurydice (2015): The European Higher Education Area in 2015: Bologna Process Implementation Report, 304 p. Luxembourg: Publications Office of the European Union [revised 2015.09.17] http://eacea.ec.europa.eu/education/ eurydice/documents/thematic_reports/182EN.pdf

7. Farkas Sz., S. Gubik A. (2013): Az egyetemi-főiskolai hallgatók vállalkozói attitüdkutatásának módszertani sajátosságai. (Methodology of evaluating the entrepreneurial attitudes of university students.), Statisztikai Szemle, 91(10). pp. 993-1012.

8. Garton, B. L., Robinson, J.S. (2006): Tracking agricultural education graduates' career choice, job satisfaction, and employability skills. Proceedings of the 2006 American Association for Agricultural Education (AAAE) National Research Conference . Charlotte, NC , p. 552-563.

9. Gibcus, P., de Kok, J., Snijders, J., Smit, L., van der Linden, B. (2012): Effects and impact of entrepreneurship programs in higher education. Prepared in 2012 for the European Commission, DG Enterprise and Industry, Brussels

10. Illés B. Cs., Dunay A., Jelonek D. (2015): The entrepreneurship in Poland and in Hungary. Future entrepreneurs education perspective. Polish Journal of Management Studies, 12:(1) pp. 48-58., https://www.scopus.com/record/display.uri?origin=inward\&eid=2-s2.0-84953233855

11. Joensen, J.S. (2009): Academic and Labour market Success: The Impact of Student Employment, Abilities, and Preferences. Social Science Research Network (SSRN), 71 p.

12. Kiss, P. (2013): Graduates' job satisfaction. In: Hungarian graduates, 2011, 261-286. Educatio Public Services Non-profit LLC, Budapest.

13. Krawczyk, E (2014): Instruments for higher education adjustment to local labour market needs. Polish Journal of Management Studies, Vol. 1., 104-114

14. Mijic D., Jankovic D. (2014): Using ICT to Support Alumni Data Collection in Higher Education Croatian Journal of Education Vol.16; No. 4, pp. 1147-1172. DOI: $10.15516 /$ cje.v16i4.613

15. Sipos, N.; Kuráth, G. (2013): The Graduate Tracking and Attainment Model at the University of Pécs. Journal of Education Culture and Society, 2013 (2), pp. 247-261. DOI: $10.15503 /$ jecs20132-247-261

16. Storen, L.A., Aamodt, P.O. (2010): The Quality of Higher Education and Employability of Graduates. Quality in Higher Education, 16:(3), pp. 297-313.

DOI: $10.1080 / 13538322.2010 .506726$

17. Szerb, L., Trumbull, W.N. (2015): Entrepreneurship and entrepreneurial ecosystem in the V4 countries: The Global Entrepreneurship Index perspective. In: Proceedings of the 5th International Conference on Management. Management, leadership and strategy for SMEs' competitiveness. Szent István University Publishing House, Gödöllő, pp. 2-7. DOI: 10.17626/dBEM.ICoM.P00.2015.p001

18. Thorp, H. and Goldstein, B. (2010): Engines of Innovation: The Entrepreneurial University in the Twenty-First century. Chapel Hill, University of North Carolina Press

19. Usher, A.; Marcucci, P. (2011): Survey of graduate tracking systems around the world. Management of Sustainable Development (Special Issue - UNESCO), 7-13. 
Vinogradov, S.

20. Varga, J. (2013): Labour market success of higher education graduates in 2011. In: Hungarian graduates, 2011, 143-167. Educatio Public Services Non-profit LLC, Budapest.

21. Veciana, J.M., Aponte, M., Urbano, D. (2005): University Students' Attitudes Towards Entrepreneurship: A Two Countries Comparison. The International Entrepreneurship and Management Journal. 1 (2): 165-182. DOI:10.1007/s11365-005-1127-5

22. Veroszta, Zs. (2013): The way to master programmes - an examination of the selection mechanisms in the Bachelor/Master transition in higher education. In: Hungarian graduates, 2011, 9-36. Educatio Public Services Non-profit LLC, Budapest.

23. Vinogradov S. A.; Fekete-Farkas, M.; Tóth-Naár, Zs. (2015): Determinants of the Labour market Success of students graduated in Szent István University in Hungary. Vadyba: Journal Of Management 27:(2) pp. 27-31. 